Maciej Ptaszyński

Institute of History

University of Warsaw

\title{
For a Rebellious Early Modern Europe. Notes on the Margins of the Most Recent Works by Luise Schorn-Schütte*
}

The early modern age dubbed itself a "new" era, distinguishing itself, in Christoph Cellarius' description, from the middle age and antiquity. ${ }^{1}$ This novitas was marked by cultural, social, religious, and political changes, not always positively evaluated by their contemporaries. With the onset of mental changes at the turn of the nineteenth and twentieth centuries, the early modern era became a historical period preceding and preparing the coming of modernity. This was the formation time of schemata which - in the spirit of Max Weber and Ernst Troelsch - defined the early modern period in terms of rationalisation, secularisation, and the separation of state from Church, and

* The article reviews the following: L. Schorn-Schütte, Gottes Wort und Menschenherrschaft. Politisch-Theologische Sprachen im Europa der Frühen Neuzeit (München, 2015), 302 pp.; eadem, Perspectum. Ausgewählte Aufsätze zur Frühen Neuzeit und Historiographiegeschichte anlässlich ihres 65. Geburtstages, ed. A. Kürbis, H. Kürbis, M. Friedrich (München, 2015; Historische Zeitschrift, Beihefte, N.S., vol. 61), 419 pp. Research financed by the Polish National Science Centre, decision number DEC-2013/09/B/HS3/00604.

1 "In primis Ecclesiae reformatio meretur, ut novam historiam, distinctam ab illa quae medii aevi fuit, ex saeculo decimo sexto, aut prope illius initia, auspicemur"; Ch. Cellarius, Historia Nova, hoc est XVI et XVII saeculorum qua eiusdem auctoris historiae, antiqua et mediiaevi, ad nostra tempora continenti ordine proferuntur, cum notis erpetuis et indice rerum (Halle, 1696), p. 3. 
politics from religion. ${ }^{2}$ Historiography was swept by a fascination with the state, its functioning, and bureaucratic structures - a child of the early modern era, and a powerful hegemon of the twentieth century. This was the formation time of historiosophical clichés, which, in the spirit of the "hermeneutics of suspicion" (Sigmund Freud, Karl Marx, or Friedrich Nietzsche), ascribed unarticulated motivations to actions by historical actors, or assigned unintended consequences to said actions. ${ }^{3}$ As Arndt Bendecke has recently shown, those historiographic accounts were often underpinned by a schema - grounded in Hegelian concepts - that propelled the search for reasons and antecedences of historical phenomena in invisible processes and transformations, or "the invisible essence" ("unsichtbare Wesentlichkeit"). ${ }^{4}$

Luise Schorn-Schütte, who specialises in early modern social and confessional history and in the early twentieth-century history of historiography, argues in her works that the early modern era was not merely the beginning and the "incubator" of modernity. In her recent monograph Gottes Wort und Menschenherrschaft, she poses questions about the uniqueness of this "new era", tracing it back to the community of systems of knowledge and values reflected in the language used by theologians and lawyers to describe the relations between religion and politics. The historiographic and methodological bases of her argument are elaborated in the volume Perspectum, comprising thirteen articles written between 1976 and 2004. Published in 2015,

${ }^{2}$ Cf. criticism in B. Stollberg-Rilinger, "Die Frühe Neuzeit - eine Epoche der Formalisierung," in: Die Frühe Neuzeit. Revisionen einer Epoche, ed. A. Höfele, J.-D. Müller, W. Österreicher (Berlin, Boston, and Göttingen, 2013), pp. 3-27; C. Zwierlein, "Frühe Neuzeit, Multiple Modernities, Globale Sattelzeit," in: Frühe Neue Zeiten. Zeitwissen zwischen Reformation und Revolution, ed. A. Landwehr (Bielefeld, 2012), pp. 389-406; J. Duindam, "Early Modern Europe. Beyond the Structures of Modernization and National Historiography," European History Quarterly 40 (2010), pp. 606-623. Recently in an essay-like form in B.S. Gregory, The Unintended Reformation. How a Religious Revolution Secularized Society (Cambridge, 2012).

${ }^{3}$ See B. Steiner, Nebenfolgen in der Geschichte. Eine historische Soziologie reflexiver Modernisierung (Berlin, München, and Boston, 2015); cf. also C. Zwierlein, "Return to Premodern Times? - Contemporary Security Studies, the Early Modern Holy Roman Empire, and Coping with Achronies," German Studies Review 38 (2015), pp. 373-392.

${ }^{4}$ A. Brendecke, "Eine tiefe, frühe, neue Zeit. Anmerkungen zur 'hidden agenda' der Frühneuzeitforschung," in: Die Frühe Neuzeit, pp. 29-45. 
the volume, a birthday present, contains a bibliography of her work published to date; foreword by Markus Friedrich profiles SchornSchütte as a scholar investigating the early modern era.

Perspectuum documents the scholarship trajectory of a historian who began her career from studies at the intersection of law history, social history, and regional studies. An important landmark was her doctoral dissertation on the eminent German historian Karl Gotthard Lamprecht (1866-1915), pioneer of cultural history ("Kulturgeschichte"), written under the supervision of Gerhard Oestreicher and defended in 1981 in Osnabrück. ${ }^{5}$ Schorn-Schütte has found that Lamprecht, who postulated situating regional history in a universal context and combining social and cultural history, made a strong mark on the German, French, and American historiography of the twentieth century. ${ }^{6}$ It is worth emphasising that Schorn-Schütte has also noted Lamprecht's impact on Polish historiography: among his students in Leipzig was Wacław Sobieski, and Lamprecht's work aroused the interest of Ludwik Finkel. ${ }^{7}$ This early historiographic study of Lamprecht foreshadows themes present in Schorn-Schütte's later works, whether those developing new approaches and theoretical models relevant to the early modern period, or elaborating on selected analytical issues.

The methods Schorn-Schütte adopts in her study Gottes Wort und Menschenherrschaft owe much to the Cambridge School tradition of historians of ideas who, after John R. Pocock and Quentin Skinner, programmatically abandoned analyses of the grand works of the classical history of ideas, instead turning to the examination of texts less ground-breaking but more popular and representative of the given era's thinking. This broader inclusion of non-primary sources also entailed a call for historians of ideas to contextualise their arguments, which would bring social history closer to the strands of history of ideas that

${ }^{5}$ L. Schorn-Schütte, Karl Lamprecht. Kulturgeschichtsschreibung zwischen Wissenschaft und Politik (Göttingen, 1984).

${ }^{6}$ See eadem, "Territorialgeschichte, Provinzialgeschichte - Landesgeschichte, Regionalgeschichte. Ein Beitrag zur Wissenschaftsgeschichte der Landesgeschichte," in: Perspectum, pp. 111-143; eadem, "Karl Lamprecht. Wegbereiter der historischen Sozialwissenschaft," in: ibidem, pp. 144-190; eadem, "Nachwirkungen der Lamprechtschen Geschichtschreibung. Rezeption im Ausland und in der deutschen Geschichtswissenschaft und Soziologie," in: ibidem, pp. 191-212.

${ }^{7}$ Eadem, Karl Lamprecht. Kulturgeschichtsschreibung, pp. 331-335; see also a Ph.D. thesis supervised by L. Schorn-Schütte: M. Ogrin, Ernst Bernheim (18501942). Historiker und Wissenschaftspolitiker im Kaiserreich und in der Weimarer Republik (Stuttgart, 2012), pp. 333-338. 
derive from political science and philosophy. Schorn-Schütte notes that the aim of these attempts was not to search for the antecedences of the present, but rather to understand what was distinct, describe the changes, and capture the processuality of historical development. ${ }^{8}$

The author of Gottes Wort und Menschenherrschaft has also examined political language. Using the example of the debates in the Holy Roman Empire between 1530 and 1650 (Chapter 2, pp. 31-130), juxtaposed with the debates in England, France, the Netherlands, Austria, and the Commonwealth (Chapter 3, pp. 131-184), she presents the early modern problems of the sources and limitations of secular power. The starting point of her discussion is the widely-held historiographic thesis typically attributed to Ernst Troeltsch that ascribes political passivity and conformity to Lutheranism, contrasting it with the disobedient, rebellious, and democratic Calvinism. ${ }^{9}$ Schorn-Schütte counters or relativises this claim, pointing to a long tradition of resistance against secular authorities in Lutheranism.

The starting point of Schorn-Schütte's scholarship must be pinned to the moment of the political consolidation of Protestants and the debates on protestation during the Diet of Speyer (1529) and the formation of the Schmalkaldic League (1530-1532). She juxtaposes the opinion of the influential Lazarus Spengler (1479-1534), who considered violence unacceptable and recommended yielding to the emperor, and the letter of Johannes Bugenhagen, written in 1530 during the absence of Martin Luther and Philip Melanchthon from Wittenberg. ${ }^{10}$ Bugenhagen refutes the passage from St Paul's letter to the Romans (Romans 13) which insists on absolute subjection to the authorities by referring to a passage from the First Book of Samuel: "I will not return with you. For you have rejected the word of the Lord, and the Lord has rejected you from being king over Israel" (1 Samuel 15:26-28). ${ }^{11}$ Since all power comes from God, specific obligations

${ }^{8}$ Schorn-Schütte, Gottes Wort, p. 20; for more on the subject: eadem, Historische Politikforschung. Eine Einführung (München, 2006), pp. 53-58.

9 For more see: eadem, “Ernst Troeltschs 'Soziallehren' und die gegenwärtige Frühneuzeitforschung. Zur Diskussion um die Bedeutung von Luthertum und Calvinismus für die Entstehung der modernen Welt," in: eadem, Perspectum, pp. 213-231.

10 Eadem, Gottes Wort, pp. 35-40.

${ }^{11}$ Bugenhagen's opinion quoted in Das Widerstandsrecht als Problem der deutschen Protestanten, ed. H. Scheible (Gütersloh, 1982), pp. 25-29; see analysis in D. Böttcher, Ungehorsam Oder Widerstand? Zum Fortleben des mittelalterlichen Widerstandrechtes in der Reformationszeit (1529-1530) (Berlin, 1991), pp. 23-25. 
are imposed on the ruler in the matters of faith and worship. When the ruler fails to meet these obligations, his rule loses legitimacy. Over the two subsequent decades, this argument would be accepted not only by Philip Melanchthon, but also many leading Lutheran theologians (such as Andreas Osiander) or less well-known clergymen (such as Georg von Waltersdorff) and lawyers (such as Johannes von der Wyck, Erastus Albert, or Basilius Monner). ${ }^{12}$

The debate over the right to resist secular authorities intensified in the late $1540 \mathrm{~s}$, when, following a military confrontation, the emperor defeated Protestants, dictating the terms of a peace agreement in Augsburg. The Augsburg Interim restored the Catholic teaching on justification, seven sacraments, the mass, and the worship of saints, as well as episcopal courts and numerous Catholic ceremonies. The sole Protestant elements preserved were communion under both kinds and the acknowledgment of existing marriages of priests. ${ }^{13}$ For Lutheran clergymen, the Interim was the gravest crisis since the Reformation: after the death of Martin Luther, there was no authority figure to lead the theologians.

The assessment of the Augsburg Interim poses a challenge for historiography. The publication of the document in 1548 evoked very diverse reactions; therefore, a separate history of the struggle would need to be written for every territory of the Holy Roman Empire of Germany and for numerous cities. Until 1971, when Horst Rabe published the first modern and analytical study on the reception of the Interim in the Empire, these issues had been among the most neglected areas of German history. ${ }^{14}$ Schorn-Schütte considers this neglect to have resulted from two historiographic tendencies: the focus of much Reformation research on the person of Martin Luther, who died in 1546, and the interest of German historiography in the Holy Roman Empire of Germany understood in terms of its state and national

${ }^{12}$ Cf.: Schorn-Schütte, Gottes Wort, pp. 52-53; eadem, "Justifying Force in Early Modern Doctrines on Self-Defence and Resistance," in: The European Wars of Religion. An Interdisciplinary Reassessment of Sources, Interpretations, and Myths, ed. W. Palaver, H. Rudolph, D. Regensburger (Farnham, 2016), pp. 139-164.

13 Das Augsburger Interim: nach den Reichstagsakten deutsch und lateinisch, ed. J. Mehlhausen (Neukirchen, 1970).

${ }^{14}$ Cf.: H. Rabe, Reichsbund und Interim. Die Verfassung- und Religionspolitik Karls $V$. und der Reichstag von Augsburg 1547/1548 (Köln, 1971); idem, "Entstehung des Augsburger Interims 1547/48," Archiv für Reformationsgeschichte 94 (2003), pp. 6-104. 
unity. ${ }^{15}$ This oversight has recently been addressed in the scholarship of Schorn-Schütte herself and in the work of Irene Dingel. ${ }^{16}$

In Gottes Wort und Menschenherrschaft, the author does not reconstruct the complex process of introducing new regulations in the territories of the Empire, but points to the resistance of many theologians against the Augsburg Interim. In their writings, Justus Menius, Georg Major, Justus Jonas or Friedrich Myconius debated not just theological problems, but also matters of politics. The most renowned and the most significant arguments against the Interim and the emperor were articulated by Lutheran clergymen based in Magdeburg, which refused to accept the Interim and for over a year, between 1549 to 1550 , resisted the army of the imperial coalition. ${ }^{17}$ Similarly uncompromising was the stance of Lutheran clergy in numerous local skirmishes in the late sixteenth and the early seventeenth centuries. Schorn-Schütte finds that theological-political language was shaped in the debates over the limits of secular authorities at the turn of the $1630 \mathrm{~s}$ and 1640 s, and its fullest expression is the dispute over the Interim. The claims and argumentation devised at the time were deployed in most sixteenth- and seventeenth-century controversies across confessional and political divides.

All the debates would usually draw on claims considered to be mutually supportive rather than exclusive or competing. They included biblical obligations (1 Samuel 15:26) as well as descriptions of the structure of the Holy Roman Empire, where the lower magistrate ("magistratus inferior") was entitled to defend the subjects even against the emperor. The classical figure of the tyrant as an anti-ruler who assaults his subjects was also deployed in the debate. Finally, owing to among others Melanchthon, references were made to "natural law" ("lex naturae") and Roman law allowing self-defence when in danger (“vim vi repellere licet”).

${ }^{15}$ Cf. L. Schorn-Schütte, "Das Interim (1548/1550) im europäischen Kontext. Eine wissenschaftliche Einleitung," in: Das Interim. Herrschaftskrise und Glaubenskonflikt, ed. eadem (Gütersloh, 2005), pp. 15-44, here pp. 18-33.

${ }^{16}$ Besides Das Interim note should be taken of Ph.D. theses supervised by L. Schorn-Schütte: A. Moritz, Interim und Apokalypse. Die religiöse Vereinheitlichungsversuche Karls V. im Spiegel der magdeburgischen Publizistik 1548-1551/52 (Tübingen, 2009); R. Berwinkel, Weltliche Macht und geistlicher Anspruch. Die Hansestadt Stralsund im Konfikt um das Augsburger Interim (Berlin, 2008); see also Reaktionen auf das Augsburger Interim, ed. I. Dingel (Göttingen, 2010).

${ }^{17}$ Cf. Schorn-Schütte, Gottes Wort, pp. 59-63. 
Schorn-Schütte puts particular emphasis on the figure of the three estates comprising the social universe, which first appeared in European thought around the eleventh century, introduced by Adalberon of Laon and Gerard of Cambrai, and gradually came to take hold over the mediaeval imagination, both in the Aristotelian and the Platonic tradition. ${ }^{18}$ The idea of the three estates, dominant in the fifteenth century, saw society as divided into laboratores, oratores, and bellatores, whose respective tasks were the provision of food, prayer, and the defence of the Christian world. At the time of the Reformation watershed, theologians did not initially refer to this tradition, reluctant as they were to embrace remnants of scholasticism. Of greater importance to the thought of Martin Luther and the nascent Reformation was making a distinction between two realms ("zwei Reiche") or two kinds of government ("zwei Regimente"), which entailed the separation of the Kingdom of God from the earthly realm. The Church and the state were thus not represented as opponents or as entities subordinated one to the other, but ones that act independently of one another. ${ }^{19}$ Gradually, however, more frequent references appeared in Lutheran thought to a tripartite division of society into the Church, secular authorities, and the home ("Kirche, Obrigkeit und Haus"), or ecclesia, politica, oeconomia. The mediaeval concept thus began to resurface in the mid-sixteenth century, although one significant difference was that it no longer distinguished the fighting bellatores and the working laboratores. Instead, its elements were the married life and secular authority. This adaptation resulted from the gradual return of Aristotelian philosophy to Protestant universities as well as from the catechistic tradition and reflection over the fourth commandment, where the family (oeconomia) is presented as a paradigm of higher authority. This concept enabled criticism of monastics, who removed themselves from society, as well as the introduction

18 See: eadem, "Die Drei-Stände-Lehre im reformatorischen Umbruch," in: eadem, Perspectum, pp. 251-280; eadem, "Drei-Stände-Lehre," in: Das Luther-Lexikon, ed. V. Leppin, G. Schneider-Ludorff (Regensburg, 2014), pp. 174-176; O. G. Oexle, "Die funktionale Dreiteilung der 'Gesellschaft' bei Adalbert von Laon,” Frühmittelalterliche Studien 12 (1978), pp. 1-54; G. Duby, Les trois ordres ou l'imaginaire du féodalisme (Paris, 1979).

${ }^{19}$ Cf.: H. Bornkamm, "Luthers Lehre von den zwei Reichen im Zusammenhang seiner Theologie," Archiv für Reformationsgeschichte 49 (1958), pp. 26-49; V. Mantey, Zwei Schwerte - Zwei Reiche. Martin Luthers Zwei-Reiche-Lehre vor ihrem spätmittelalterlichen Hintergrund (Tübingen, 2005), pp. 157-293, here pp. 245-259. 
of ethics into Lutheran thought. This vision of the social order bridged Luther's "two regiments", entirely separate in his original vision. It was quickly adopted by lawyers and authors of popular domestic literature ("Hausväterliteratur"). ${ }^{20}$ In the sixteenth and seventeenth centuries, the concept of the three estates became an important argument in the debates between the clergy and secular authorities, when the former assumed the role of the latter's censors. A functional equivalence of the estates allowed their representatives to assess and criticise each other's actions. Schorn-Schütte argues this figure was present across confessional divides.

The Commonwealth of Poland and Lithuania is an exception against the backdrop of the European tradition of resistance. Schorn-Schütte finds that legal arguments are pivotal to, and all but dominate, the debate on secular authority and its limits in the country. ${ }^{21}$ Following to-date historiographic findings, she emphasises the legalism that typified the political culture of Polish nobility and the significance of the codification of the right to resist in the Privilege of Mielnik of 1501, then in the Henrician Articles, reformulated during Zebrzydowski's rokosz (semi-legal rebellion, 1606/1609). It is worth noting that a closer look at the tradition of resistance against authorities reveals first and foremost its mediaeval roots, and shows that it has at least five strands constituted by: (1) mediaeval privileges, (2) mediaeval international agreements, (3) mediaeval Aristotelianism, (4) the Privilege of Mielnik, (5) early modern political theory. These are briefly outlined below. ${ }^{22}$

In Poland, the tradition of the right to resist can be traced back to the thirteenth-fifteenth centuries, with over ten documents from that period using a formula of renouncing obedience as a guarantee in a treaty. ${ }^{23}$

20 See also a Ph.D. thesis supervised by L. Schorn-Schütte: Ph. Hahn, Das Haus im Buch. Konzeption, Publikationsgeschichte und Leserschaft der 'Oeconomia' Johann Colers (Epfendorf, 2013).

${ }^{21}$ Schorn-Schütte, Gottes Wort, p. 192, Table 7.

22 A comprehensive discussion in Diskussionen über Notwehr, Gegenwehr, Widerstandsrecht und das Gewissen. Normwandel in ständepolitischen Debatten im Europa des 16./17. Jahrhunderts, ed. L. Schorn-Schütte [forthcoming]; see also M. Ptaszyński, "Zwischen Gemeinwohl und Staatsräson. Das Widerstandsrecht in den Ständedebatten der polnisch-litauischen Republik im 16. Jahrhundert,” in: Frühneuzeitliche Reiche in Europa. Empires in Early Modern Europe, ed. T. Gromelski, Ch. Preusse, A. Ross, D. Tricoire (Wiesbaden, 2016), pp. 67-87.

23 See: A. Vetulani, Studia nad tekstami i znaczeniem statutu tęczyckiego z r. 1180 (Lwów, 1932); J. Adamus, "Mniemana łęczycka ustawa sukcesyjna roku 1180," 
The formula was conditional and typically fairly conventional: should the sovereign breach the privilege granted in a document, the subjects are released from their duty of obedience. The second tradition was that of international treatises, primarily peace treaties with the Teutonic Order in the fourteenth and fifteenth centuries; from the Treaty of Kalisz (1343), the Treaty of Melno (1422), to the Peace of Brześć Kujawski (1435), these treaties included a clause about renouncing obedience. ${ }^{24}$ In both these traditions, the right to resist had its foundation in the mediaeval category of fidelity (fides), on which the social system was based. Fides obligated subjects to provide auxilium and consilium, and rulers to defend and guarantee justice. The breach of this duty by one party freed the other from its obligations. The tradition of mediaeval privileges issued to senators and nobles, bestowing on them the right to admonish the sovereign, included the Privilege of Mielnik issued in 1501. Although it opened a new era, the exposition uses the figure - central to European tradition - of the tyrant, contrasted with universum regnum released from its oath of fidelity ("universum regnum sit liberum a iuramento et fide praestita"). ${ }^{25}$ The Privilege was in fact never implemented, but it was well-remembered when the end of Sigismund II Augustus's reign drew near, and the much-debated document became a model for the formula included

Collectanea Theologica 17 (1936), pp. 183-206; idem, "Prawo oporu w Polsce średniowiecznej," Sprawozdania z Czynności i Posiedzeń Eódzkiego Towarzystwa Naukowego 14 (1959), pp. 1-4; J. Wyrozumski, "Od ius resistendi do ius de non praestanda oboedientia w Polsce," in: Świat, Europa, mata ojczyzna. Studia ofiarowane profesorowi Stanistawowi Grodziskiemu w 80-lecie urodzin, ed. M. Małecki (Bielsko-Biała, 2009), pp. 155-164.

${ }^{24}$ Cf.: E. Weise, Das Widerstandsrecht im Deutschordenslande Preussen und das mittelalterliche Europa (Göttingen, 1955), pp. 144-145; Codex Diplomaticus Regni Poloniae et Magni Ducatus Lituaniae, vol. 4, ed. M. Dogiel (Vilnae, 1764), no. 65, p. 70; Dokumenty strony polsko-litewskiej pokoju metneńskiego z 1422 roku, ed. P. Nowak, P. Pokora (Poznań, 2004), p. 9; Die Staatsverträge des Deutschen Ordens in Preußen im 15. Jahrhundert, vol. 1: 1398-1437, ed. E. Weise (Königsberg, 1939), nos 152-154, pp. 150-164, here p. 163; ibidem, nos 179-183, pp. 195-213, here p. 210; Acten der Ständetage Preussens unter der Herrschaft des Deutschen Ordens, vol. 2, ed. M. Toeppen (Leipzig, 1880), no. 108, pp. 170-176.

25 Volumina Constitutionum, vol. 1, ed. S. Grodziski, I. Dwornicka, W. Uruszczak (Warszawa, 1996), pp. 109-113; see also: L. Sobolewski, W. Uruszczak, "Artykuły mielnickie z roku 1501," Czasopismo Prawno-Historyczne 42 (1990), pp. 31-61; F. Papée, "Przywilej mielnicki," in: Księga pamiatkowa ku czci Oswalda Balzera, vol. 2, ed. W. Abraham, P. Dąbrowski, L. Pieniński (Lwów, 1926), pp. 173-187. 
in the Henrician Articles (1573). ${ }^{26}$ These Articles, which contained both a guarantee of peace between dissidents in faith and the clause about renouncing obedience, would be referenced by numerous polemicists in the centuries to come. ${ }^{27}$

A separate tradition was created by Aristotelians teaching or educated at the Cracow University in the fifteenth century. Commentaries on Aristotle's Politics, lectures, treatises, and sermons developed the ideas of contractarianism, the common good, and the sovereignty of law. ${ }^{28}$ The doctrine of the right to resist, formulated in Aristotelian terms, was referenced by scholars writing works justifying the rebellion of Prussian estates against the Teutonic Order, and the aid provided by Poland and Lithuania to these rebels. ${ }^{29}$ This academic tradition, which drew from conciliaristic debates, was formative for sixteenthcentury political theory; within it, an element of the theory of resistance or renouncing obedience appears in the writings of Andrzej Zaborowski, Frycz Modrzewski, Stanisław Orzechowski, or Andrzej Wolan. ${ }^{30}$

26 On the articles see: D. Makiłła, Artykuty Henrykowskie (1573-1576). Geneza - obowiazywanie - stosowanie. Studium historyczno-prawne (Warszawa, 2012); M. Ptaszyński, "Die polnischen Wahlkapitulationen des 16. Jahrhunderts und ihr Fortleben im 17. Jahrhundert," in: Wahlkapitulationen in Europa, ed. H. Duchhardt (Göttingen, 2015), pp. 59-72.

27 See p. ex.: J. Crell, O wolność sumienia, trans. I. Lichońska, ed. Z. Ogonowski (Warszawa, 1957); [D. Kałaj], Rozmowa Przyiacielska, ministra ewanielickiego z xiedzem katolickim (s.l., 1671) - here dedication: "A jesliby się co stało temu naprzeciwko / abo in personam Regis, tedy ab omni fide \& obedientia Regibus debita solvuntur subditi, abo in personam alicujus, vel aliquarum ex Civibus Regni, tedy przeciwko takim / pacis \& securitatis Dissidentium violatoribus, obiecują Status Regni, sub fide honore \& conscientia związani pro se \& succesoribus, powstać y znosić"; [D. E. Jabłoński], Jura et libertates Dissidentium in Religione Christiana, in Regno Poloniae et M.D. Lithuaniae ex Legibus Regni et aliis Monumentis authenticis excerpta (Berlin, 1708). On disputes about the confederation see M. Korolko, Klejnot swobodnego sumienia. Polemika wokót konfederacji warszawskiej $w$ latach 1573-1658 (Warszawa, 1974).

${ }^{28}$ Cf. P. Czartoryski, Wczesna recepcja 'Polityki' Arystotelesa na Uniwersytecie Krakowskim (Wrocław, 1963).

${ }^{29}$ K. Górski, "Polski traktat polityczny w obronie Związku Pruskiego," Rocznik Olsztyński 7-8 (1968), pp. 163, 171; idem, "Pisma polskie w obronie Związku Pruskiego a geneza Złotej Wolności,” Roczniki Historyczne 18 (1949), pp. 143-173; idem, "Rządy wewnętrzne Kazimierza Jagiellończyka," in: M. Biskup, K. Górski, Kazimierz Jagiellończyk. Zbiór studiów o Polsce drugiej połowy XV wieku (Warszawa, 1987), pp. 82-128, here pp. 92-93; Weise, Das Widerstandsrecht, pp. 156, 163-165.

${ }^{30}$ H. Litwin, "W poszukiwaniu rodowodu demokracji szlacheckiej. Polska myśli polityczna w piśmiennictwie XV i początków XVI wieku,” in: Między monarcha 
There is no doubt that the relation of this theory of resistance to political practice was completely distinct in Poland, where confessional confrontations never matched the intensity of those in the Holy Roman Empire, in France, or in England. It should be noted, however, that there was a broad array of the forms of and possibilities for resistance in the early modern era: from criticising and admonishing the sovereign to active defence of one's rights, where a rokosz or an outright rebellion were the most radical solutions. Instances of the practice of admonishing the sovereign are described in historical works from the times of Wincenty Kadłubek and Jan Długosz. ${ }^{31}$ Records of the proceedings of Sejms and sejmiks, starting from the Sejm of 1548, show multiple instances of critical comments directed at the king, or even threats against the monarch. ${ }^{32}$ References to the Gliniany rokosz (1379-1380) and the Lviv rokosz (1537) were made across the entire early modern period. The former was historical fiction, while the latter was a manifestation of the dissatisfaction of the nobility and its leaders, who admonished the king and queen, demanding that political obligations be honoured..$^{33}$

Rumours about an imminent rokosz spread around Poland in 1549, after Sigismund II Augustus did not yield to the pressure of the estates

a demokracją. Studia z dziejów Polski XV-XVIII wieku, ed. M. Żaryn, A. Sucheni-Grabowska (Warszawa, 1994), pp. 13-53.

31 E.g., Magistri Vincentii dicti Kadtubek Cronica Polonorum, ed. M. Plezia (Kraków, 1994), I, 13. On this passage see S. Witkowski, "Podstęp Leszka z kolcami u Kadłubka i jego źródło," in: Księga pamiątkowa ku czci Oswalda Balzera, vol. 2, pp. 677-690.

32 Cf.: "Lecz iż Korona polska nie przyrodzonem prawem na WKM przyszła, nie podbiłeś nas mocą, ani mieczem swobodnymi ludźmi będąc, nie będąc tego powinni, jeno z nadziei tej, któreśmy o WKMci jeszcze w dzieciństwie WKMci wybralichmy cię sobie za Pana nie inszym sposobem, jedno, iżbyś wolnym ludziom panował a nie inaczej, jeno wedle prawa, a swobód naszych, a chociaż królowie polscy tak swobodnym ludziom rozkazywali, sławnie przedsię panowali," “Dyaryusz sejmu piotrkowskiego 1548," in: Dyaryusze sejmów koronnych 1548, 1553 i 1570 r., ed. J. Szujski (Kraków, 1872), pp. 221-222. Similar wording during the Sejms of 1553 and 1563 was noted in "Dyaryusz sejmu krakowskiego r. 1553," in: ibidem, p. 1; Źrzódtopisma do dziejów Unii Korony Polskiej $i$ W. Księstwa Litewskiego, ed. A. T. Działyński (Poznań, 1856), p. 6.

${ }^{33}$ H.-J. Bömelburg, Polska myśl historyczna a humanistyczna historia narodowa (1500-1700), trans. Z. Owczarek, introduction A. Lawaty (Kraków, 2011), pp. 281, 172-173; M. Wyszomirska, "Rokosz Gliniański i Rady Kallimacha a doktryna złotej wolności,” in: Nad spoteczeństwem staropolskim, vol. 1, ed. W. Walczak, K. Łopatecki (Białystok, 2007), pp. 73-82; A. Prochaska, "Rokosz lwowski w r. 1537," Kwartalnik Historyczny 16 (1902), pp. 1-22, 208-242, 381-400. 
concerning his marriage to Barbara Radziwiłłówna. The obligations listed in the Henrician Articles had to be implemented in practice following the flight of Henry III of Valois from Poland in $1574 .{ }^{34} \mathrm{How}-$ ever, the most intense confrontation between the monarch and the estates took place at the beginning of the reign of Sigismund III Vasa. The conflict escalated at the 1592 Sejm and during Zebrzydowski's rokosz (1606-1607/1609). ${ }^{35}$ The latter was not just an opportunity to admonish the king, but led to the relinquishing of allegiance to the monarch. ${ }^{36}$ During the gatherings at which the decision was taken to open the legal proceedings, the numerous and futile admonishments issued to date served as justification. Stanisław Stadnicki, an avid advocate of deposing Sigismund III, was believed to have made the following statement at a gathering near Lublin that opened the rokosz in 1606: "You say send envoys, admonish the king. For eighteen years we have been admonishing him, and he cares nothing; what is the name of the Article that he has not invoked?" He added that the practice of admonishing the king was futile, for so far the king "has used silence to wriggle his way out of everything". ${ }^{37}$

While emphasising the legalist mind-set of the nobility and its respect for the institution of monarchy, it is easy to overextend these beliefs - well-evidenced in Sejm speeches or political writing - onto the entire political nation. Despite the assurances of fidelity and respect for the rule of law, Poland did experience attempts to assassinate monarchs. The attempt on the life of Sigismund I in 1523 is shrouded in mystery. ${ }^{38}$ At the 1569 Sejm, Sigismund II Augustus was reported to have demanded changes to the Privilege of Mielnik because he feared for his life: "Be it sooner or later, you must

${ }^{34}$ W. Zakrzewski, Po ucieczce Henryka. Dzieje bezkrólewia 1574-1575 (Kraków, 1878).

35 Cf.: K. Lepszy, Rzeczpospolita Polska w dobie sejmu inkwizycyjnego (1589-1592) (Kraków, 1939); J. Maciszewski, Wojna domowa w Polsce (1606-1609), vol. 1 (Warszawa, 1969). Recently on the rokosz: E. Opaliński, "Zjazd rokoszowy warszawski w październiku 1607 r.," Kwartalnik Historyczny 121, no. 3 (2014), pp. 521-539.

${ }^{36}$ Cf. H. Wisner, "Wypowiedzenie posłuszeństwa czy detronizacja Zygmunta III?," Czasopismo Prawno-Historyczne 39, 1987, pp. 173-185.

37 Diary of the "Gathering by Lublin", copy Cracow, Czartoryski Library (Biblioteka Czartoryskich), MS 343, pp. 131-161 (copy Warsaw, National Library [Biblioteka Narodowa], Mf 11670), p. 152 (“O toż tak Ja, Stanisław Stadnicki z Łańcuta, Króla Zygmunta III nie mam za Pana i nie przyznawam, bo mi prawo złamał i wolę umrzeć, niż go za Pana mieć").

38 See Z. Wojciechowski, Zygmunt Stary (1506-1548) (Warszawa, 1979), p. 190, fn. 23. 
alter this statute's de crimine Maiestatis, perhaps you want someone to put a dagger or a bullet in my side" ${ }^{39}$ Compared with these, the most infamous assassination attempt - perhaps because it was actually made - was that by Michał Piekarski in 1621, who was able to strike Sigismund III with a hatchet. ${ }^{40}$

To conclude this brief list, it must be emphasised that Schorn-Schütte is correct in her assumptions and her thesis about the commonality of political tradition which found its expression in the debate on the limits of secular authorities. In the Polish and Lithuanian Commonwealth, theological argumentation was, however, rarely deployed against the monarch. ${ }^{41}$ This did not result from a lack of information about the situation in Western Europe, or from the lack of familiarity about the debates held there, but from the specificity of the political culture in the sixteenth-century Poland. The complexity of this reception can be briefly demonstrated with the example of the Augsburg Interim.

The Interim was relevant to the power of the Jagiellon dynasty, as the emperor attempted to persuade the Duchy of Prussia's ruler Albrecht to accept the document, while Albrecht considered himself a defender of Martin Luther's teaching. Copies of documents relating to the Interim were immediately sent to Cracow, and then to Königsberg, where fears were expressed that these documents were proof that Reformation was at an end. ${ }^{42}$ Bishop of Augsburg, Cardinal Otto Truchseß, issued an ultimatum to Albrecht: only by accepting the emperor's compromise would he obtain the emperor's consent to his marriage to Catherine Jagiellon that Albrecht was seeking at the time. The Duke of Prussia and his agent supposed that the responsibility for this unfavourable answer rested with Bishop Samuel Maciejowski or Queen Bona Sforza. ${ }^{43}$

39 Dyaryusze sejmowe r. 1585, ed. A. Czuczyński (Kraków, 1901), pp. 185-186.

40 U. Augustyniak, Wazowie i 'królowie rodacy'. Studium wtadzy królewskiej w Rzeczypospolitej XVII wieku (Warszawa, 1999), p. 118.

41 Cf. eadem, "Wstęp," in: Państwo świeckie czy księże? Spór o rolę duchowieństwa katolickiego w Rzeczypospolitej w czasach Zygmunta III Wazy. Wybór tekstów, ed. U. Augustyniak (Warszawa, 2013), pp. 103-104.

42 See: Elementa ad fontium editiones, vol. 38, ed. C. Lanckorońska (Romae, 19601992), no. 1163, pp. 119-122: K. Konarski to Albrecht, Cracow, 25 April 1549 (sends Albrecht a copy); ibidem, no. 1164, pp. 122-124: S. Bojanowski to Albrecht, Cracow, 29 April 1549.

43 Cf.: ibidem, no. 1195, pp. 166-167: S. Bojanowski to Albrecht, Cracow, 14 Nov. 1549 ("Item offensam esse Suam Ilustrissimam Dominacionem Augustani 
In June 1549, John a Lasco (Jan Łaski), the most eminent Polish Protestant theologian living outside Poland for several years, came to Prussia to meet Albrecht. ${ }^{44}$ According to Oskar Bartel, Lasco did not only seek the king and queen's consent to his return to Poland, but also participated in talks about a possible new Protestant alliance against the Habsburgs. ${ }^{45}$ After his meeting with the duke, Lasco was recalled to Emden in East Frisia, where work was ongoing on a new version of the Interim, to be approved by the clergy working in the Duchy. Many clergymen, including superintendent Lasco, rejected the document. They objected to the idea of appointing priests to celebrate mass and to the obligation to wear linen surplices when distributing the eucharist, performing baptism, and preaching sermons. As a result of the dispute, churches were closed to the opponents of the Interim; they therefore resorted to preaching at schools or in cemeteries. ${ }^{46}$ The escalation of the conflict forced Lasco to leave the duchy and move to Bremen in October 1549, and subsequently to Hamburg. Lasco's involuntary journey, caused by the Interim, came to an end in May 1550, when he arrived in England. ${ }^{47}$

The royal court was aware of the situation in the Empire after the Interim from direct accounts by Stanisław Hozjusz and Andrzej Frycz Modrzewski, who in 1549 undertook a diplomatic journey to Vienna, Antwerp, and Brussels. ${ }^{48}$ In April 1549, Chancellor Samuel Maciejowski asked Hozjusz to send him the documents of which they spoke before the latter's departure, especially the constitutions

et nostri Cracoviensis Episcopis practica, qui Suae Ill. Dominacioni sororem Regis certo promittebant, si Interim recipiat"); Elementa, vol. 43, no. 78, pp. 79-80 (G. Tarło to Albrecht, Piotrków, 30 Nov. 1548).

${ }^{44}$ See H. Jürgens, Johannes a Lasco in Ostfriesland: der Werdegang eines europäischen Reformators (Tübingen, 2002), pp. 334-335.

45 O. Bartel, Jan Easki (Warszawa, 1999), p. 163; see also Joannis a Lasco Opera tam edita quam inedita, vol. 2, ed. A. Kuyper (Amstelodami, 1866), no. 58, p. 628: J. Łaski to Hardenberg, Gdańsk, 1 Aug. 1549.

46 A lengthy description in Elementa, vol. 38, no. 1196 [=Kuyper, Opera, vol. 2, no. 59, pp. 628-632]: J. Łaski to Albrecht, Emden, 18 Sept. 1549; discussion in Bartel, Jan Easki, pp. 164-165; Jürgens, Johannes a Lasco, pp. 340-341.

47 Bartel, Jan Easki, pp. 165-166; Jürgens, Johannes a Lasco, pp. 340-344.

48 On the mission: A. Sucheni-Grabowska, "Stanisław Hozjusz jako dyplomata Zygmunta Augusta. Wokół Traktatu Praskiego z 1549 roku," Studia Warmińskie 18 (1981), pp. 99-156, here pp. 142-143; Z. Wurst, "Legacya Stanisława Hozyusza cesarza Karola V i króla Ferdynanda I w roku 1549," Przewodnik Naukowy i Literacki 31 (1903), here pp. 193-194. 
adopted in Augsburg. ${ }^{49}$ However, supporting the anti-imperial faction was not among the political goals of the young Jagiellon's court, on the contrary - the aim was to seek the support of the Habsburgs in the conflicts against the opposition in Poland. In his famed letter of 18 June, Sigismund II Augustus recommends that Hozjusz have a private conversation with Ferdinand and convey regrets over past misunderstandings. ${ }^{50}$ The king is asking for Ferdinand's advice, complaining about domestic opposition and adding that he has sought, unsuccessfully, to overcome the opposition's resistance by means of kindness rather than strict measures. ${ }^{51}$ An alliance between Ferdinand and Sigismund II Augustus was signed on 2 July 1549; it contained a clause on aid against rebels. ${ }^{52}$

Soon, Gniezno provost Andrzej Czarnkowski was also dispatched to the court of Ferdinand. ${ }^{53}$ The envoy was instructed to offer, on behalf of Sigismund II Augustus, assistance with the Council of Trent, to put forward the proposal of a meeting between the two monarchs, and to invite Ferdinand's envoys to participate in the imminent Sejm. ${ }^{54}$ Czarnkowski sought to convince Ferdinand that resistance

49 "Libros, de quibus locutus sum cum Dne. V. R., mitti mihi velim, praesertim constitutiones Augustani conventus," S. Maciejowski to Hozjusz, Cracow, 29 April 1549, in Stanislai Hosii... Epistolae, vol. 1, ed. F. Hipler (Cracoviae, 1879), no. 322, pp. 302-303.

${ }^{50}$ Cf. Sigismund II Augustus to Hozjusz, Cracow, 18 June 1549, in: ibidem, no. 344, pp. 329-331.

51 "Quorum nos voluntates ferendo aliquantisper emollire studemus: neque enim a severitate et asperitate auspicari regnum nobis est in animo, sed lenitate et clementia maiorum nostrorum instituto animos nostrorum hominum adiungere nobis cupimus. Verum si forte minime victi patientia et facilitate nostra, molesti porro nobis esse pergerent ac de omnibus seu de dignitate etiam nostra detrahere conarentur, quid tunc nobis faciendum esse censeat Mtas. eius?,” ibidem; letter discussed by Wurst, "Legacya," p. 391.

52 Warsaw, Central Archives of Historical Records (Archiwum Główne Akt Dawnych), Dok. Pergaminowe, no. 5425; Haus-, Hof- und Staatsarchiv (Vienna) [hereafter: HHStA], Polonica I, box 6, fasc. 1, fol. 43r-62r, 64r-70r; printed in Codex Diplomaticus Regni Poloniae et Magni Ducatus Lituaniae, vol. 1, ed. M. Dogiel (Vilnae, 1759), pp. 213-219; see Sucheni-Grabowska, "Stanisław Hozjusz," p. 79, fn. 1.

${ }^{53}$ HHStA, Polen I, box 6, fasc. 1, fol. 93: Sigismund II Augustus to Ferdinand, Cracow, 3 Dec. 1549; ibidem, fol. 104: S. Maciejowski to Ferdinand, Cracow, 4 Dec. 1549. Mentioned in Elementa, vol. 38, no. 1215, pp. 188-189: A. Cikowski to Albrecht, Cracow, 11 Dec. 1549. Wurst, "Legacya," p. 676, incorrectly calls him Adam.

${ }^{54}$ HHStA, Polonica I, box 6, fasc. 1, fol. 107-108: "Instructio," Cracow, 6 Dec. 1549. 
against Sigismund II Augustus was the work of a small group based in Greater Poland and led by Andrzej Górka. Górka, the Greater Poland starosta, had the support of Archbishop Mikołaj Dzierzgowski and Great Crown Marshal Piotr Kmita, as well as that of the Brandenburg elector. ${ }^{55}$ Ferdinand's response was very favourable. The Emperor, well-informed of the confrontations between Sigismund II Augustus and the opposition at the Piotrków Sejm, deplored the rebellions and conspiracies against the monarch. ${ }^{56}$ Even so, he recommended leniency and encouraged the king to go to great lengths to avoid fratricidal strife, the spilling of Christian blood, or taking up arms against his subjects, which would only weaken and depopulate the country. ${ }^{57}$ Instead, he advised that Sigismund II Augustus strip those members of the political elite who resisted the king of their offices and honours. He also warned against allowing a disease that had already affected Greater Poland to spread in Little Poland.

On his return to Poland, Hozjusz gave an account of his mission at the Piotrków Sejm on 23 June $1550 .{ }^{58}$ The paths of the two Humanists - Frycz and Hozjusz - diverged quickly, though both referenced the Augsburg Interim in their works. Though he drew closer to the Protestant camp, Frycz mentioned the Interim in his work $O$ poprawie Rzeczypospolitej (On the Improvement of the Commonwealth), believing the Augsburg project a genuine/viable attempt at a compromise solution to the confessional conflict. The chapters on penitence in another of his works, $O$ kościele (On Church), quote the text of the Interim and passages from the polemical writing of Philip Melanchthon and John Calvin. ${ }^{59}$ Interestingly, Melanchthon's opinions on

55 Unsigned and undated text of the legation in HHStA, Polonica I, box 6, fasc. 1, fol. 140-149; see Wurst, "Legacya," pp. 677-679.

${ }^{56}$ HHStA, Polonica I, box 6, fasc. 1, fol. 128-133, 135-140: "Responsum pro Ser. Regis Oratore" ("esse videlicet nonnullos, qui contra Ser.tem. eius tumultus et seditiones excitare, ac alios in factionem suam protrahere, adeoq. publicam Regni quietem et tranquillitatem turbare non cessent").

57 Cf.: "cum primis autem Ser.ti eius consulit a bello, quod non contra externos hostes, sed intra viscera Regni futurum esset, quod fieri queat, magnopere cavendum esse," ibidem.

58 Cf. Stanislai Hosii... Epistolae, vol. 1, nos. 376-377, pp. 372-392.

59 Cf.: "Etsi illa satisfactio, quae culpam et aeternam poenam expiat, soli Christo tribuenda est, satisfactio tamen, quae in poenitentiae fructibus constistit [! should be: consistit], maxime autem in ieiunio, eleemosyna et oratione siue a nobis suscepta, siue a parochis et dispensatoribus sacramentorum iniuncta, si ex fide et charitate peragitur, peccatorum causas excindit et peccati reliquiis 
the Interim were also referenced by Marcin Kromer, who disagreed with the confession presented by deputies during the 1555 Sejm. ${ }^{60}$ A dozen or so years later, Hozjusz, an opponent of Frycz, again used the example of the Interim in a text on the reading of the Bible by lay persons, which he viewed as reprehensible. Hozjusz believed that by restoring some Catholic ceremonies, the Interim allowed Lutherans to not reveal their confession: "those who accepted the Interim were Lutherans then as they had been before, only they eat no meat on Fridays and not in the Lent, and when they say their ungodly mass, they use priestly vestments in some places". ${ }^{61}$ Paradoxically, it was the writer close to the Protestant camp and a close collaborator of John a Lasco who spoke favourably about the imperial document, while the Catholic, a sworn enemy of Protestantism, criticised the Interim for excessive laxity.

Thus, the Interim was well known in Poland, but never evoked a reaction among Protestants that would be in any way comparable to the vivid disputes conducted in Western Europe. On the contrary, many circles welcomed the imperial document as a compromise proposal, one that would allow a rapprochement between Catholics and Protestants. This appears to be evidence of a delay in the shaping of a confessional awareness of Polish Protestants, since the Interim was not a direct threat to them. Protestant churches in Poland would develop clear confessional features only in the second half of the sixteenth century.

The scarcity of recourse to the language of theology in the debate on the limits of authority in the Crown does not, however, undermine the key claim about the universal character of political language and political arguments. There are instances where the figure of the three estates is used in the Kingdom of Poland, whether in an Aristotelian-scholastical spirit, or as part of current debates about the social obligation of the estates. The tradition of commentaries on Aristotle's writings up until the early seventeenth century, and Przydatki (Addenda) by Sebastian Petrycy of Pilzno, are the context for

medetur ac temporalem poenam uel tollit, uel mitigat et in exemplum denique adhibetur," Andreae Fricii Modrevii Commentariorum de republica emendanda: libri quinque, ed. K. Kumaniecki (Warszawa, 1953), p. 133, p. 356; this passage in Das Augsburger Interim, p. 85.

${ }^{60}$ Cf. L. Finkel, "Konfesya podana przez posłów na sejmie piotrkowskim w r. 1555," Kwartalnik Historyczny 10 (1896), pp. 276-285, here p. 270.

${ }^{61}$ See S. Hozjusz, Księgi o jasnym a szczyrym stowie bożym, ed. M. Korolko (Kraków, 1998), pp. 116-117. 
the schema ethica - economia - politica, which corresponds to the main branches of philosophy as well as the spaces of social life. In printed popular literature, the motif of the three estates appears at its birth in Mikołaj Rej's Krótka rozprawa między Panem, Wójtem a Plebanem (A Short Discussion Between Three Persons: a Squire, a Bailiff, and a Priest), a work in the Reformation spirit not only due to its stinging criticism of the clergy, but also by its reference to the category of "righteous faith", guaranteeing salvation regardless of works. ${ }^{62}$ In pamphlets and polemical writing of the second half of the sixteenth century, a similar distinction appears in Andrzej Wolan's treatise $O$ wolnosici szlacheckiej (On the liberty of nobility). Wolan divided society into three estates: nobles, burgesses, and labourers ("nobiles, oppidiani, aut agricolae"). ${ }^{63}$ By so doing, Wolan excluded the institution of the church from the earthly realm.

References and appeals to the concept of the three estates of society can be encountered not only in Stanisław Orzechowski's manifesto, but also in handwritten correspondence of Catholic polemicists. Soon after the death of Piotr Tomicki, bishop Jan Latalski noted in a letter to Sigismund that the Cracow bishop had rendered great services to the king and "the republic of the kingdom both profane and ecclesiastical". ${ }^{64}$ As is believed by the publishers of Hosius's correspondence, the expression "respublica ecclesiastica Regni" may have been penned by the future bishop of Warmia, who was at the time staying at Latalski's court. Similar references to the concept of "respublica ecclesiastica", devised to defend the rights of the Church, are noted in later correspondence of bishops and canons. ${ }^{65}$ It appears that in

${ }^{62}$ Cf. J. T. Maciuszko, Mikotaj Rej. Zapomniany teolog ewangelicki z XVI w. (Warszawa, 2002), pp. 59-79.

63 A. Wolan, De libertate politica sive civili, ed. M. Eder, R. Mazurkiewicz (Warszawa, 2010), pp. 104-106.

${ }^{64}$ Cf.: "Non longe abierit Sacra Mtas. V. Antecessor meus Petrus Tomicius, vir et de Sacra Mte. V. et de Republica tam profana quam ecclesiastica Regni huius optime meritus, in cuius ego locum beneficio Sacrae Mtis. V. successi,” J. Latalski to Sigismund II Augustus, Cracow, Oct. 1536, in Stanislai Hosii... Epistolae, vol. 1, no. 21, pp. 40-42.

65 See Stanislai Hosii... Epistolae, vol. 2, pt. 2, no. 1663: S. Hozjusz to S. Karnkowski, Lidzbark Warmiński, 19 Sept. 1556 ("Petunt enim, ut iura unius ordinis, ecclesiastici nimirum, labefactet, quae se conservaturam aeque iuraverit atque iura alterius ordinis. Quod si libere volunt Mti suae, ut una in re violet iusiurandum suum, eadem opera licitum illi fore, ut etiam illud, quod ordini saeculari praestitit iusiurandum violet"). 
the writings of Catholic polemicists, the terms "status ecclesiasticus" or "respublica ecclesiastica" took on political significance as an argument raised in defence of the position of the Catholic church, one of the estates of society. Further, it is in the letters of Hozjusz that one can find the categorical phrasing "oportet Deo magis oboedire quam hominibus" (Acts 5:29). ${ }^{66} \mathrm{He}$ uses it about the king, not wanting to concede to the demands of Protestants in Chełmno and Elblag. The passage from the Book of Samuel recurred in the writings of Catholic hierarchs and others who exchanged letters with Hozjusz, calling upon laymen to retain fidelity to the Roman Church and the traditional faith. ${ }^{67}$ Hozjusz invoked New and Old Testament formulae traditionally referenced in disputes between the ecclesiastical and secular authorities. Sigismund II Augustus, at whom those often hysterical attacks and protestations were directed, wrote understandingly that the bishop was merely performing his duty ("officium"). ${ }^{68}$

Recapitulating the above reflections, one must yet again emphasise the correctness of Schorn-Schütte's thesis: there existed in the early modern era a Europe-wide language of politics based on a common academic education, a shared system of values, and a generally

${ }^{66}$ See ibidem, no. 1613, pp. 717-718: S. Hozjusz to S. Karnkowski, Lidzbark Warmiński, 4 June 1556 ("Nam si datum fuerit mandatum tale, respondebo vobis breviter: Oportet oboedire Deo magis quam hominibus; sin autem absoluta potestate uti volueritis, quid aliud ex eo colligam quam quod me Episcopum esse non vultis"); ibidem, no. 1838: S. Hozjusz to Sigismund II Augustus, Lidzbark Warmiński, 3 Oct. 1557 ("Ubi autem Dei causa agitur, non mihi licet aliud dicere, quam quod illi dixerunt: "oportet oboedire magis Deo quam hominibs"”); ibidem, no. 1960, pp. 902-903: S. Hozjusz to M. Dzierzgowski, Lidzbark Warmiński, 19 Oct. 1557 (“Accepi autem litteras Regiae Mtis. ipsius manu subscriptas, quibus postulat, ut eum loco ne moveam. Ego vero Mti. eius respondi, quod oportet magis oboedire Deo quam hominibus; simul petivi, ne quid eiusmodi imperat mihi Mtas. eius, quae mihi catholico Episcopo facere non licet").

67 See ibidem, no. 1296, p. 473: P. Głogowski to S. Hozjusz, Pułtusk, 26 Nov. 1554 (reference to 1 Samuel 15:28, as a conclusion of a long argument: "Ceterum qua diligentia quantove studio a maioribus nostris erat prospectum, ne unitas fidei apud nos scinderetur, annales nostros atque statua, quae quottidie manibus suis terunt, videant. Certe hac ipsa maiorum nostrorum diligentia effectum est, ut apud nos Christianae religionis integritas nullo hactenus novitatis nidore esset infecta et depositum hoc ita ab illis conservatum, ut incorruptum omnino ad nostra usque tempora transmiserint").

68 See ibidem, vol. 2, pt. 1, no. 1319, p. 487: to S. Hozjusz, Rudniki, 10 Jan. 1555 ("Facit Ptas. V. officium suum, quae nos de rebus is admonet, quae ad retinendam veterem religionem tranquillitatemque terrerum nostrarum Prussiae pertinere putat"). 
familiar system of references, metaphors, and figures. In Poland and in the Commonwealth, the canonisation of the right to resist at the turn of the Middle Ages and the early modern era, and then the adoption in 1573 of confessional guarantees combined with the formula of renouncing obedience, meant that Protestants, defending their position, used the traditional form of self-defence and invoked liberties and privileges. From this vantage point, early modern Europe - in its own view - did not actually know rebels: everyone merely guarded their own rights, liberties, and privileges. ${ }^{69}$

Yet, even this legalistic language of freedom was so deeply immersed in religion that it is impossible to separate the discourses of politics and confession. To describe this specific language, Schorn-Schütte uses the term "political theology", which she borrows from Carl Schmitt. In Schmitt's striking phrasing, "all the important concepts in today's political science of the state are secularised theological concepts". ${ }^{70}$ While Schmitt's original phrase applied first and foremost to the origins of the modern understanding of politics and postulates an analogy between law and theology, Schorn-Schütte seeks to capture the uniqueness of the political language of the early modern era. Recently, the history of thus defined "political theology" has been presented from the vantage point of a historian of philosophy by Merio Scatolla, who defined it as "rational discourse about the shared lives of people". ${ }^{71}$ To reduce the key processes in the early modern era to the formation of the absolutist state, secularisation, and the separation of religion from politics, or seeking therein the beginnings of modernity and an "invisible essence" which was yet to reveal itself,

${ }^{69}$ Cf. L. Schorn-Schütte, "Kommunikation über Herrschaft. Obrigkeitskritik im 16. Jahrhundert," in: eadem, Perspectum, pp. 299-342; R. v. Friedeburg, "In Defense of Patria. Resisting Magistrates and the Duties of Patriots in the Empire from the 1530s to the 1640s," Sixteenth Century Journal 32 (2001), pp. 357-382.

70 See C. Schmitt, Politische Theologie. Vier Kapitel zur Lehre von der Souveränität (Berlin, 2004), p. 43. On Schmitt's notion of 'political theology' see J. Manemann, Carl Schmitt und die Politische Theologie. Politischer Anti-Monotheismus (Münster, 2002), pp. 87-201, here p. ex. p. 99 ("Schmitts politische Theologie, die gewissermaßen als Frühreaktion auf die in der Zeit nach dem Ersten Weltkrieg sich ausbildende reflexive Modernisierung zu verstehen ist, bietet nun in diesen Gemengelagen sozialer Desorganisation und des Zerfalls von Traditionen eine Verhaltenslehre, die durch radikale Unterscheidungen Vertrautszonen herzustellen und Identitäten zu bestimmen versucht").

${ }^{71}$ M. Scattola, Teologia politica (Bologna, 2007), p. 11. 
is to distort the image of the period. Schorn-Schütte gives justice to the early modern era, revealing it as a time of constant clashes and of establishing limits.

Maciej Ptaszyński, PhD, assistant professor at the Institute of History, University of Warsaw. He researches the history of the Polish Reformation, particularly its relations to European Reformation and its eminent figures and late Humanism in the Commonwealth.

E-mail: m.ptaszynski@uw.edu.pl

Trans. by Bartosz Wójcik

First published as: "O buntowniczą nowożytność. Uwagi na marginesie najnowszych prac Luise Schorn-Schütte," Odrodzenie i Reformacja w Polsce 60 (2016), pp. 255-272

The publication of this English translation has received additional funding from the Ministry of Science and Higher Education of the Republic of Poland 